\title{
Street Law, Inc.: Context, History and Future
}

\author{
Lee Arbetman ${ }^{1}$
}

\section{Introduction}

In 1972, a small group of Georgetown University law students developed a series of practical law lessons for use with public high school students in Washington, D.C. These visionaries recognized that ordinary citizens-not just lawyers-needed a basic understanding of practical law in order to take on civic responsibilities. The lessons were popular with the high school students and with their law student teachers. Responding to their practical nature, the high school students called these lessons "Street Law." The name stuck. ${ }^{2}$

A pilot program in two local high schools in 1972-73 launched a movement-first in the United States but eventually around the world - to teach the public about law and public

\footnotetext{
${ }^{1}$ Lee Arbetman is executive director of Street Law, Inc., a nonprofit, nonpartisan organization located just outside Washington, D.C. Lee is a graduate of Grinnell College (B.A. in history), the University of Massachusetts (M. Ed. in social studies education), and George Washington University Law School (J.D.). He has taught at the elementary school, middle school, high school, college, and law school levels. He is the co-author of Street Law: A Course in Practical Law and the developer of many of Street Law's programs. He has delivered Street Law training and technical assistance in Mexico, Ukraine, Turkey, and Georgia.

${ }^{2}$ Washington, D.C. and the District of Columbia are used interchangeably in this article to refer to the capital of the United States.
} 
policy using learner-centered, interactive teaching methods. Today, Street Law programs can be found in every state in the U.S. and in more than 40 countries around the world. ${ }^{3}$

Propelling this global movement to advance justice through practical education about law and democracy is Street Law, Inc., a Washington, D.C. area non-profit organization that is an outgrowth of the early Street Law program at Georgetown University Law Center. That pilot effort has also grown into a full-fledged, credit-bearing experiential education program at Georgetown that has served as a model program for more than 120 law schools across the country and around the world. Nearly 1,000 upper division Georgetown Law students have participated in this program since its inception. Many have gone on to positions as law firm partners, corporate counsel, government officials in the U.S. and abroad, and even members of the federal court bench. They have taken from their law school experience a commitment to public education about law and democracy.

The early pilot at Georgetown Law Center and the D.C. Public Schools has spawned a variety of Street Law programs delivered by teachers, lawyers, law students, judges, justice system staff (e.g., probation officers), youth workers, and police officers. Programs

\footnotetext{
${ }^{3}$ Visit www.streetlaw.org for more information about Street Law, Inc., including a map of its program activities around the world.
} 
worldwide have reached students from elementary schools to community colleges and from classrooms to the justice system and community settings.

All Street Law programs share the following three characteristics:

1. Teaching practical content: legal rights and responsibilities, obligations under the rule of law, internationally accepted human rights, and the operation of democratic systems of government

2. Using interactive teaching strategies to develop important skills: civic engagement, advocacy, problem solving, critical analysis, and communication

3. Involving the community in the educational process: subject matter experts from the legal community visit classrooms, and students go into their communities to both observe and affect law in action

The emergence of Street Law in the early 1970s was not an historical accident-it was a historical necessity. The social turbulence of the 1960s in the U.S. lead to passage of laws that affected broad segments of the public. During that decade the Supreme Court of the United States decided cases that implemented their 1954 public school desegregation cases, ${ }^{4}$ nationalized rules affecting police-citizen interaction, ${ }^{5}$ and recognized that public

\footnotetext{
${ }^{4}$ Brown v. Board of Education, 347 U.S. 483 (1954) and Brown II, 349 U.S. 294 (1955)

${ }_{5}^{5}$ Mapp v. Obio, 367 U.S. 643 (1961), prohibited the use of illegally seized evidence in state court criminal trials (the exclusionary rule); Miranda v. Arizona, 384 U.S. 436 (1966), required that police warn defendants in custodial interrogation situations that they have a right to counsel and that their testimony could be used again them (selfincrimination)
} 
IJPLE 2 (1) 2018

school students did not leave their First Amendment rights at the door. ${ }^{6}$ Additionally, the U.S. Congress passed important, far-reaching civil rights legislation in 1964, 1965, and 1968. ${ }^{7}$ Taken together these statutes and court decisions presented the American public with many laws that affected them in their daily lives. It was time for the public to become legally literate.

\section{The 1970s: Early Pilot Programs in Washington, D.C.}

The Street Law concept - teaching practical law to ordinary citizens - was first proposed in 1971 at Georgetown University Law Center. ${ }^{8}$ A Georgetown Law Center public interest law professor, Jason Newman, and four of his law students - including future Street Law, Inc. executive director Ed O'Brien-collaborated on a plan to teach law in Washington, D.C. public high schools. This group from Georgetown Law drafted the first Street Law lessons, which covered practical aspects of criminal law, juvenile justice, consumer law, family law, housing law, and individual rights and liberties. ${ }^{9}$

\footnotetext{
6 Tinker v. Des Moines, 393 U.S. 503 (1969)

${ }^{7}$ Civil Rights Act of 1964, 78 Stat. 241 (July 2, 1964) prohibited discrimination based on race, color, religion, sex, and national origin in employment and in businesses of public accommodation; Voting Rights Act of 1965, 79 Stat. 437 (August 6, 1965), prohibited racial discrimination in voting and banned literacy tests that had been used in some southern states in the U.S.; Civil Rights Act of 1968, 82 Stat. 73 (April 11, 1968), also known as the Federal Fair Housing Act, prohibited discrimination in housing.

8 The Georgetown Street Law Program has continued without interruption since 1972.

https://www.law.georgetown.edu/academics/academic-programs/clinical-programs/our-clinics/street-law-program/

9 At about the same time that Street Law was starting in Washington, D.C., the American Bar Association in Chicago, Illinois, created its Youth Education for Citizenship Committee (now known as the Division for Public Education) www.americanbar.org. The Constitutional Rights Foundation in Southern California (www.crf-usa.org) and Law in a
} 
The Street Law pioneers successfully promoted the idea of Street Law to Vincent Reed, the District of Columbia's associate superintendent of schools at the time, and the school system approved a pilot project to begin in 1972 at Woodrow Wilson and Eastern High Schools.

The Street Law pilot project culminated in a mock trial in Georgetown Law Center's moot courtroom, with the high school students trained to play the roles of attorneys and witnesses. Students' success in the first Street Law mock trial competition had a major impact on Street Law's future.

Free Society, now the Center for Civic Education (www.civiced.org) also launched. These NGOs continue to operate in 2018, and each has also had experience with democracy education programs outside the U.S. 


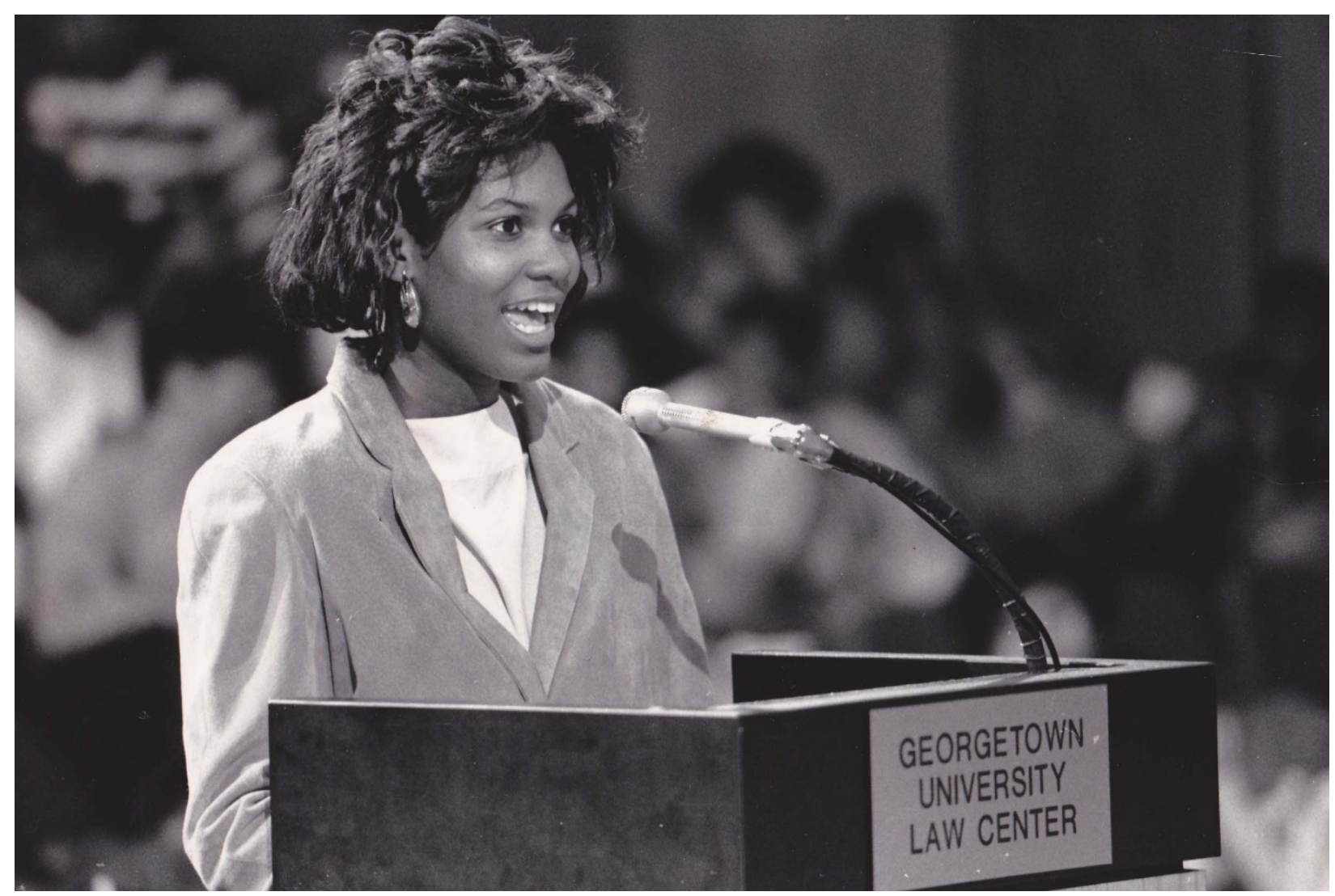

This was the first interscholastic high school mock trial competition. In short order, the mock trial competition expanded to all the D.C. public high schools. Eventually the concept spread across the country. Today the majority of states in the U.S. have high school mock trial competitions.

As evidence of success, the initial mock trial competition spread quickly to all of the Washington, D.C. public high schools and then to other states. There is now a robust national high school mock trial competition in the U.S. Winners of state competitions compete against each other at a national event that is held in a different city each year. All states and most U.S. territories send teams, and, in recent years, South Korea has also participated. ${ }^{10}$

\footnotetext{
${ }^{10}$ National High School Mock Trial Championship: www.nationalmocktrial.org
} 
Equipped with the mock trial competition, a series of tested, engaging learner-centered lessons, and inquiries from other law schools and school systems, a separate organization was formed to pursue the education of lay people about law and democracy. Throughout the 1970s, Street Law staff took the pilot program model to other U.S. law schools with much success. The early adopters of this model were the law schools at University of Notre Dame (Indiana), Cleveland State University (Ohio), University of Denver (Colorado), University of San Francisco (California), University of Tennessee (Tennessee), and University of California-Davis (California). Street Law programs can now be found at more than 70 law schools in the U.S. and more than 50 more around the world. ${ }^{11}$ Street Law, Inc. pioneered the concept of law student teaching programs and of having law schools award academic (or pro bono) credit for these programs. In the U.S. these efforts were often called Street Law, practical law, youth and the law, or civic education programs. Outside the U.S., the term Street Law term was sometimes used, but because it frequently suffered in translation into other languages, the general term "public legal education" was often used. Today, the term public legal education is widely used to describe programs that teach non-lawyers about law.

The 1970s also brought Street Law programs into prisons. The Georgetown Street Law Program began a new, parallel program model in which law students taught practical

\footnotetext{
11 Some, but not all, of these programs are identified on Street Law's map of program activities around the world at www.streetlaw.org
} 
law lessons to inmates in local jails and prisons. After correctional officers noted that they, too, needed to learn their rights, Street Law expanded the clinic to ensure that prison officials and correctional officers also understood the law. Street Law co-published a textbook to use in the program. ${ }^{12}$

\section{Street Law in the Classroom}

In the late 1970s, Street Law expanded its programming to provide professional development to high school social studies teachers. With funding from the Law Enforcement Assistance Administration at the U.S. Department of Justice, Street Law and four other organizations ${ }^{13}$ began the process of introducing what was called law-related education to the nation's schools. With consistent bipartisan support from the U.S. Congress, this program continued for nearly three decades and resulted in substantial curriculum development, training, and support for teachers, lawyers, law students, and police officers throughout the U.S.

\footnotetext{
12 O’Brien, Edward, Margaret Fisher, and David T. Austern. Practical Law for Correctional Personnel. St. Paul, MN: West Publishing Company, 1981. This publication is now out of print, and Street Law, Inc. no longer works with correctional officers. Co-author Margaret Fisher, former Street Law Inc. staffer and now Distinguished Practitioner in Residence and director of the Street Law program at Seattle University School of Law, has decades of experience working with correctional officers. She can be reached at mfisher130@gmail.com.

${ }^{13}$ American Bar Association, Youth Education for Citizenship; Law in a Free Society; Constitutional Rights Foundation; and Phi Alpha Delta Law fraternity
} 
As this national process began, Street Law staff members were encouraged to develop their lessons into a textbook. In 1974, in tandem with West Publishing Company, Street Law published a small run of textbooks for use in the Washington, D.C. program; the first national edition of Street Law: A Course in Practical Law was published in 1975. ${ }^{14}$

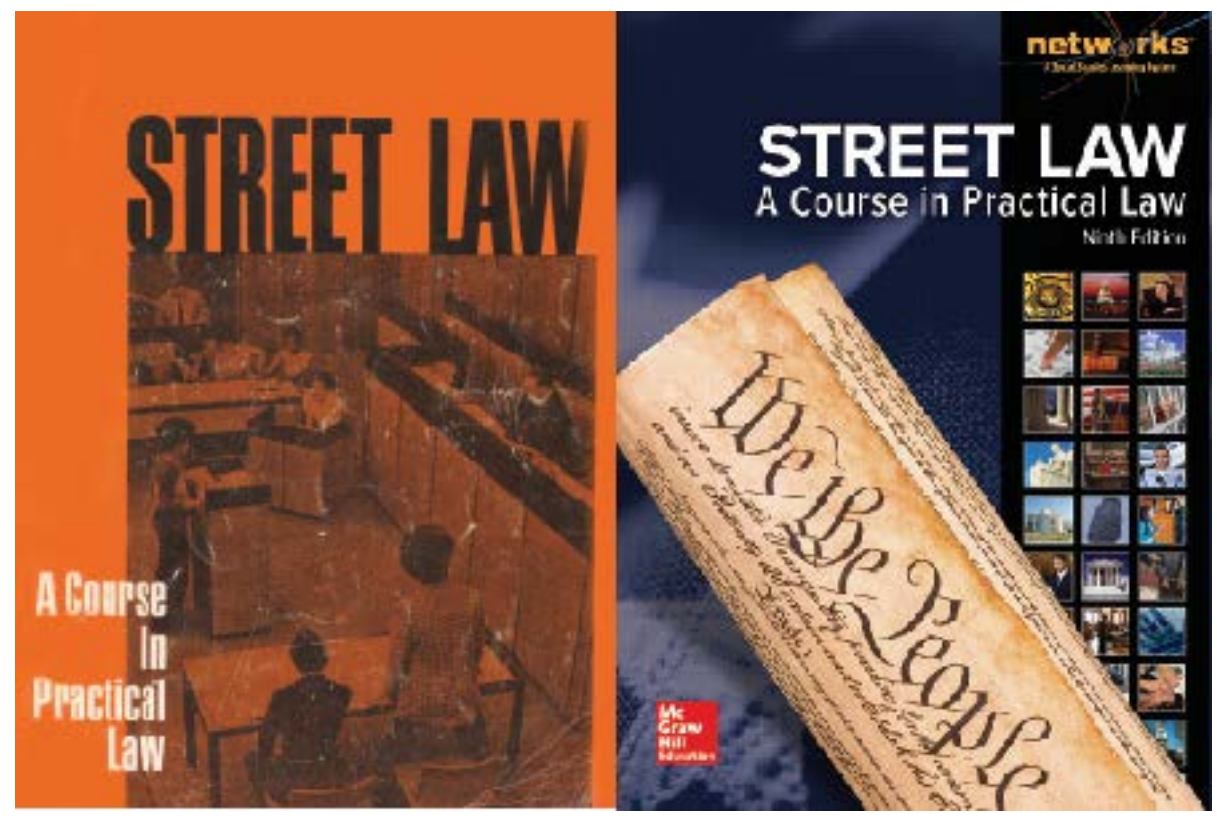

Together, Street Law and West Publishing pioneered the idea of a high school practical law textbook. Street Law's current publisher is McGraw-Hill Education and the 9th edition of the text was released in summer 2015. The various editions of Street Law have sold nearly one million copies in the United States.

The national law-related education program led to the creation of statewide civic learning programs in almost every state. Some of these were housed at state bar associations, some at law schools, while others became independent nonprofit organizations. These statewide organizations became the backbone of law-related and civic education in the

\footnotetext{
${ }^{14}$ The early editions of Street Law: A Course in Practical Law were published by West Publishing Company. The current ninth edition, (C) 2016, is published by McGraw-Hill Education.
} 
United States. From early on, the U.S. Street Law experience was importantly grounded in a multitude of effective partnerships with law schools, governments, legal practitioners, and community groups, which contributed to its scale, sustainability and ongoing success.

\section{Street Law in the Juvenile Justice System}

By the end of the 1970s, Street Law had expanded into the juvenile justice system. The Honorable Norma Holloway Johnson, a District of Columbia Superior Court judge who later became chair of Street Law's National Advisory Committee, observed a need for Street Law programming among the young people who came before her in court. She initiated a Street Law court diversion program to ensure that the young people involved in the court system understood what was happening to them in court, while also learning some legal basics. Youths attended Street Law classes every Saturday for 12 weeks. If they succeeded in the course, the charges against them were dropped. This program began with first offenders for non-violent acts, but was later expanded to juveniles charged with weapons offenses.

Street Law promoted the use of its empowering teaching strategies in juvenile justice systems nationally, and Street Law lessons have become a part of probation services in many other states. A study of the Washington, D.C. diversion program found that 
students who completed the program reduced their recidivism rate dramatically relative to other similarly situated youth who had not participated in Street Law.

\section{The 1980s: National Expansion and International Beginnings}

\section{Teens, Crime, and the Community}

In 1986, Street Law, along with the National Crime Prevention Council, ${ }^{15}$ initiated an innovative approach to crime prevention through the development of the Teens, Crime, and the Community program. This program taught middle school students about criminal and juvenile justice and how to avoid violent crime, substance abuse, child abuse, acquaintance rape, shoplifting, and property crime. Students also developed and implemented a wide range of crime prevention projects.

This crime prevention education program naturally led to the involvement of police officers. In response, Street Law developed a separate set of lessons so that these schoolbased police officers could benefit from Street Law's proven classroom pedagogy.

15 National Crime Prevention Council: www.ncpc.org 


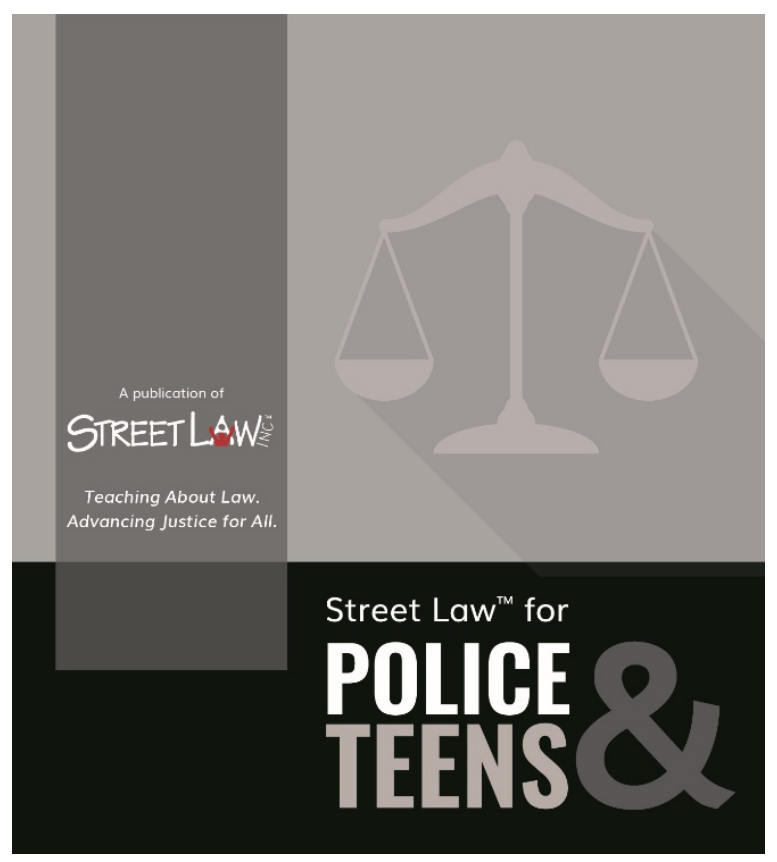

The first set of Street Law lessons for use by school resource officers was published in the late 1980s, and in 2001, Street Law received the Presidential Citation from the National Association of School Resource Officers in recognition of the classroom materials developed for SROs. In 2016, Street Law updated and expanded its lessons for school- and community-based police officers in a new publication: Street Law for Police \& Teens.

This program was important to Street Law's development for two reasons: it provided the organization with an early and positive experience with project-based learning (sometimes called action civics in the U.S.), and it began a long and fruitful series of partnerships between Street Law and law enforcement officers, in particular school resource officers whose "beat" was in and around schools. ${ }^{16}$

\footnotetext{
${ }_{16}$ In 2002, Street Law was awarded a Presidential Citation from the National Association of School Resource Officers: www.nasro.org. In 2017, Street Law completed a revised set of lessons for police officers: www.streetlaw.org/policemanual.
} 


\section{Street Law in South Africa}

In 1986, Street Law began to expand its work internationally. Professor David McQuoidMason, dean of the law faculty at the University of Natal in Durban, South Africa, met with Street Law, Inc.'s executive director, Ed O'Brien, to discuss starting a Street Law program in his country. Professor McQuoid-Mason secured funding and brought O'Brien to South Africa for a month to run workshops and share Street Law's philosophy.

Despite operating during Apartheid, the Street Law program was almost universally accepted in South Africa. Professor McQuoid-Mason worked to adapt the U.S. Street Law textbook for South Africa and convinced local high school principals to allow Street Law courses to be taught by law students. McQuoid-Mason even met with Nelson Mandela upon his release in 1990. McQuoid-Mason reported that Mandela was a big supporter of Street Law. The program expanded to 17 of the 21 law schools in South Africa and eventually added new components like a space colony simulation and mock youth parliament. ${ }^{17}$

${ }^{17}$ Street Law South Africa: www.facebook.com/StreetLawSouthAfrica 


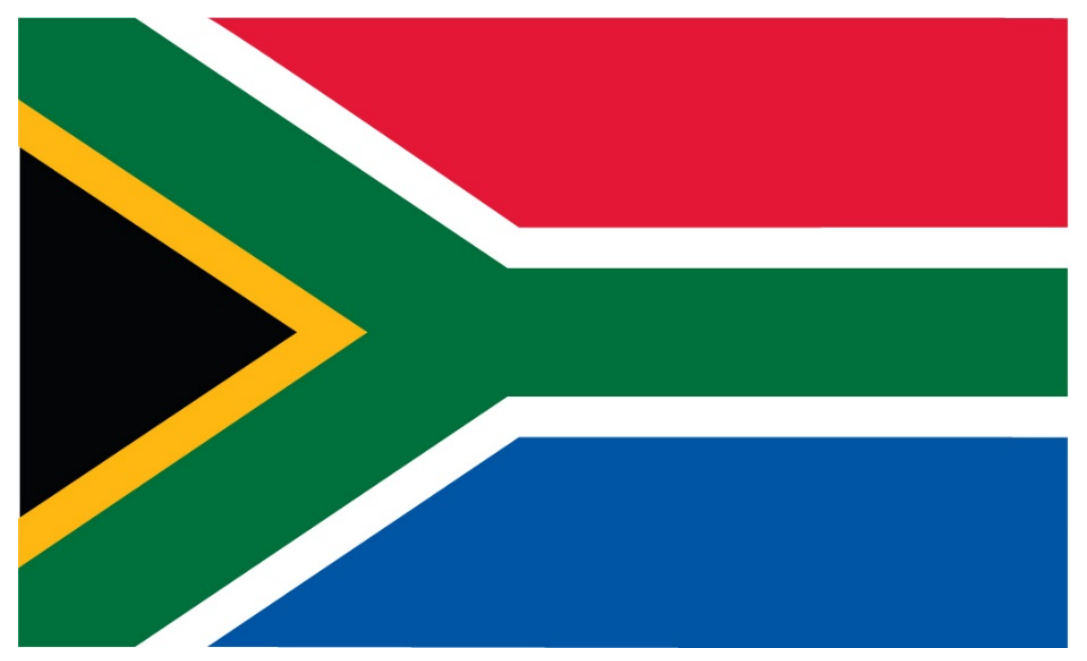

The success of the South Africa Street Law program marked the beginning of Street Law's international expansion, demonstrating that Street Law's practical law approach could work outside the U.S. - even in the most challenging of circumstances.

\section{The 1990s: International Expansion and Training U.S. High School}

\section{Teachers}

The 1990s were a critical decade for Street Law. New curricula were developed, Street Law's premier professional development program for teachers-the Supreme Court Summer Institute for Teachers-began, and significant developments were made in Street Law's international programs.

\section{Expanded Educational Programming}

Over the course of the decade, Street Law made it a priority to address the weak treatment of the U.S. Supreme Court and its cases in high school history, government, and civics textbooks. Knowing that high school students respond enthusiastically to studying real 
cases about real people, Street Law collaborated with the Supreme Court Historical Society to develop a summer institute for teachers to help them expand and improve their instruction about the Court and its role in students' lives. As the nation's leading Supreme Court advocate, John Roberts, later to become Chief Justice of the United States, worked closely with Street Law staff to create the institute. Roberts also taught in the program annually until becoming a member of the Supreme Court. Street Law has turned this opportunity into one of the nation's premier professional development programs for high school social studies teachers.

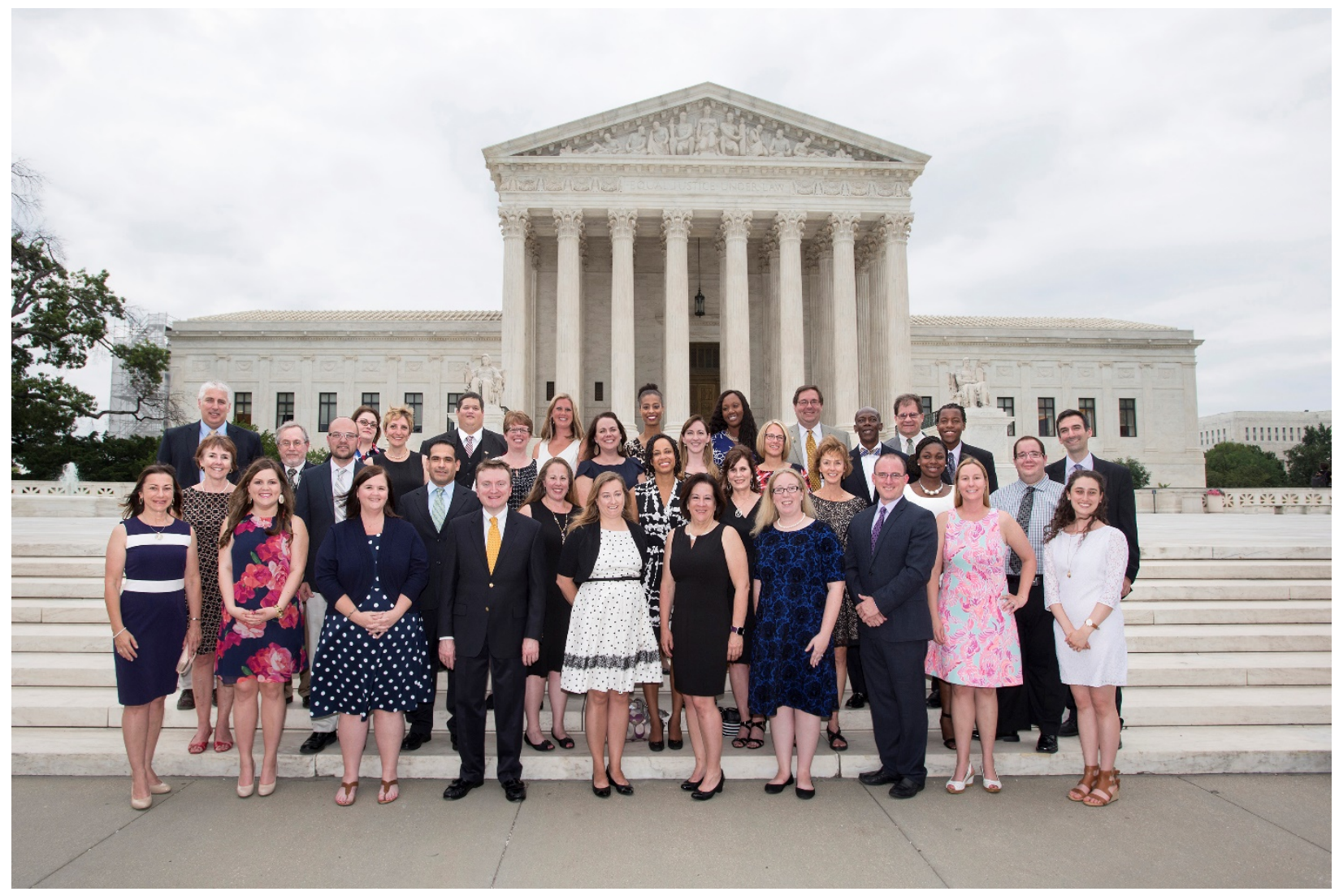

The Supreme Court Summer Institute has been conducted annually since 1995 and more than 1,200 teachers from all 50 states and the District of Columbia have participated. Each year, the Institute concludes with a visit to the Court to hear decisions and attend a reception hosted by a justice. 
Street Law and the Supreme Court Historical Society have also collaborated to develop the popular LandmarkCases.org, which provides materials that help teachers deliver engaging instruction about the Court's cases that are most often required in state social studies content standards.

In 1995, Street Law developed an innovative program to teach young parents about the law. The lesson topics covered important topics including child abuse and neglect, family law, government benefits, and rights and responsibilities of tenants. Parents and the Law classes were held in community settings and in school-based parenting education programs.

In 1993, Street Law developed a set of activities for teaching conflict resolution to young people called We Can Work It Out! ${ }^{18}$ It featured classroom lessons and mediation simulations in which students practiced their mediation skills. An adaptation of this text was published for upper elementary school students in $1998 .{ }^{19}$

Throughout the 1990s there was an expansion of high school social studies elective courses that focused on law, the majority of which used the Street Law textbook as their

\footnotetext{
18 Zimmer, Judith A. We Can Work it Out!: Problem Solving Through Mediation. Culver City, California: Social Studies School Service, 1993.

19 Zimmer, Judith A. Let's Say: “We Can Work it Out!”: Problem Solving Through Mediation. Culver City, California: Social Studies School Service, 1998.
} 
IJPLE 2 (1) 2018

primary instructional resource. After the first edition's publication in 1975, subsequent editions of Street Law: A Course in Practical Law were published every five years. ${ }^{20}$

\section{International Expansions}

In 1996, Street Law leaders in South Africa and the United States began to collaborate on a human rights textbook that could be used across borders. The result was Human Rights for All, a text that was adapted and used in a number of other countries; it was translated into Russian, Romanian, Hungarian, and Spanish. ${ }^{21}$

Encouraged by the first democratic election in South Africa in 1994, Street Law staff in South Africa and the United States collaborated to create a text that explored the components of a successful democracy in South Africa and the United States. This partnership resulted in Democracy for All, which has also been adapted and translated for use in many countries. A second edition of Democracy for All, ${ }^{22}$ completed by the South African writing team in 2017 and focused on South Africa, is available as a free online resource for educators to translate and adapt for use around the world. ${ }^{23}$

\footnotetext{
${ }^{20}$ Arbetman, Lee and Edward L. O’Brien. Street Law: A Course in Practical Law (First Edition). St. Paul: West Publishing Company, 1975; and Arbetman, Lee and Edward L. O’Brien. Street Law: A Course in Practical Law (Ninth Edition). Columbus: McGraw-Hill Education, 2016.

${ }^{21}$ O’Brien, Edward L., Eleanor Greene, and David McQuoid-Mason. Human Rights for All. Lincolnwood, IL: National Textbook Company, 1996.

22 McQuoid-Mason, David, Mandla Mchunu, Karthy Govender, Edward L. O’Brien, and Mary Curd Larkin. Democracy for All. Kenwyn, South Africa: Juta \& Co Ltd, 1994.

23 Street Law South Africa. Street Law: Democracy for All - Learner's Manual (Second Edition). Kenwyn, South Africa: Juta \& Co Ltd, 2017. https://juta.co.za/support-material/detail/street-law-democracy-for-all-learners-manual
} 
The success in South Africa led to a Street Law expansion into Central and South America, where programs were established in Chile, Ecuador, Bolivia, and Panama. Street Law staff partnered with local communities and organizations to visit program sites and edit curricular materials to fit local cultural contexts.

In 1997, Street Law received a large international grant from the Open Society Institute (Soros Foundation) to expand the Street Law experience to 17 countries, including Russia and other countries in Central and Eastern Europe and Central Asia. Street Law partnered with local NGOs and provided training to local teachers and law students. Street Law collaborated with program sites to adapt Human Rights for All and Democracy for All to fit the needs of local programs and also helped NGOs create practical law textbooks that used Street Law's learner-centered methodology. In many of those countries, Street Law staff worked with law faculty to establish legal clinics which included a law student teaching component.

In 1999, Street Law became a founding member of the Global Alliance for Justice Education $(\mathrm{GAJE})^{24}$ - a global organization committed to achieving justice though education. GAJE sponsors biennial worldwide conferences that provide networking opportunities for like-minded justice educators, in particular law school clinicians, as

${ }^{24}$ Global Alliance for Justice (GAJE): www.gaje.org 
well as a chance to learn about new Street Law programs that have taken root around the world.

By the 1990s the term Street Law was being used globally as a generic term covering a very particular aspect of public legal education. Some people ran Street Law programs that had never had any interaction with an existing program in the U.S., U.K. or South Africa. The popularity of the term presented both opportunities and challenges. The opportunities focused on the rapid spread of these programs; the challenge was that in some instances programs "reinvented the wheel" and, as might be expected, program quality was somewhat uneven.

\section{The Founding of Street Law, Inc.}

From its inception in the early 1970s until 1998, Street Law had been a project of the Consortium of Universities of Metropolitan Washington. This organization had been Street Law's legal "parent." Street Law had a prominent national advisory committee during that time, and several of the chairs of the committee had been past presidents of the American Bar Association.

In 1998, Street Law was incorporated as Street Law, Inc., a 501(c)(3) tax-exempt organization registered in the United States with a governing board of directors. 


\section{STREETLAW:}

\section{The 2000s: Diversity Pipeline Work with Companies and Law Firms}

\section{Street Law's Corporate Legal Diversity Pipeline}

In 2001, Street Law collaborated with lawyers at DuPont and the Association of Corporate

Counsel (ACC) to support increased diversity in the legal profession, through the development of Street Law's Corporate Legal Diversity Pipeline Program. ${ }^{25}$

The program, which is active today, connects diverse high school students with corporate law department volunteers. The volunteers, trained by Street Law staff, teach a series of lessons in high school social studies classrooms and then bring participating students and their teachers to the corporate headquarters for a day-long series of legal simulations and a career fair. The program is designed both to teach civil law topics and to encourage young people of color to consider law as a career option.

The Legal Diversity Pipeline Program has also been implemented with law firms in partnership with NALP (National Association for Law Placement). Nearly 2,000

\footnotetext{
${ }^{25}$ Learn more at www.streetlaw.org/acc (the program with corporate law departments) and www.streetlaw.org/nalp (the program with law firms). In a number of instances hybrid programs arose with law departments working with their law firm partners.
} 
American lawyers devoted an average of 10 volunteer hours each to this program in 2016.

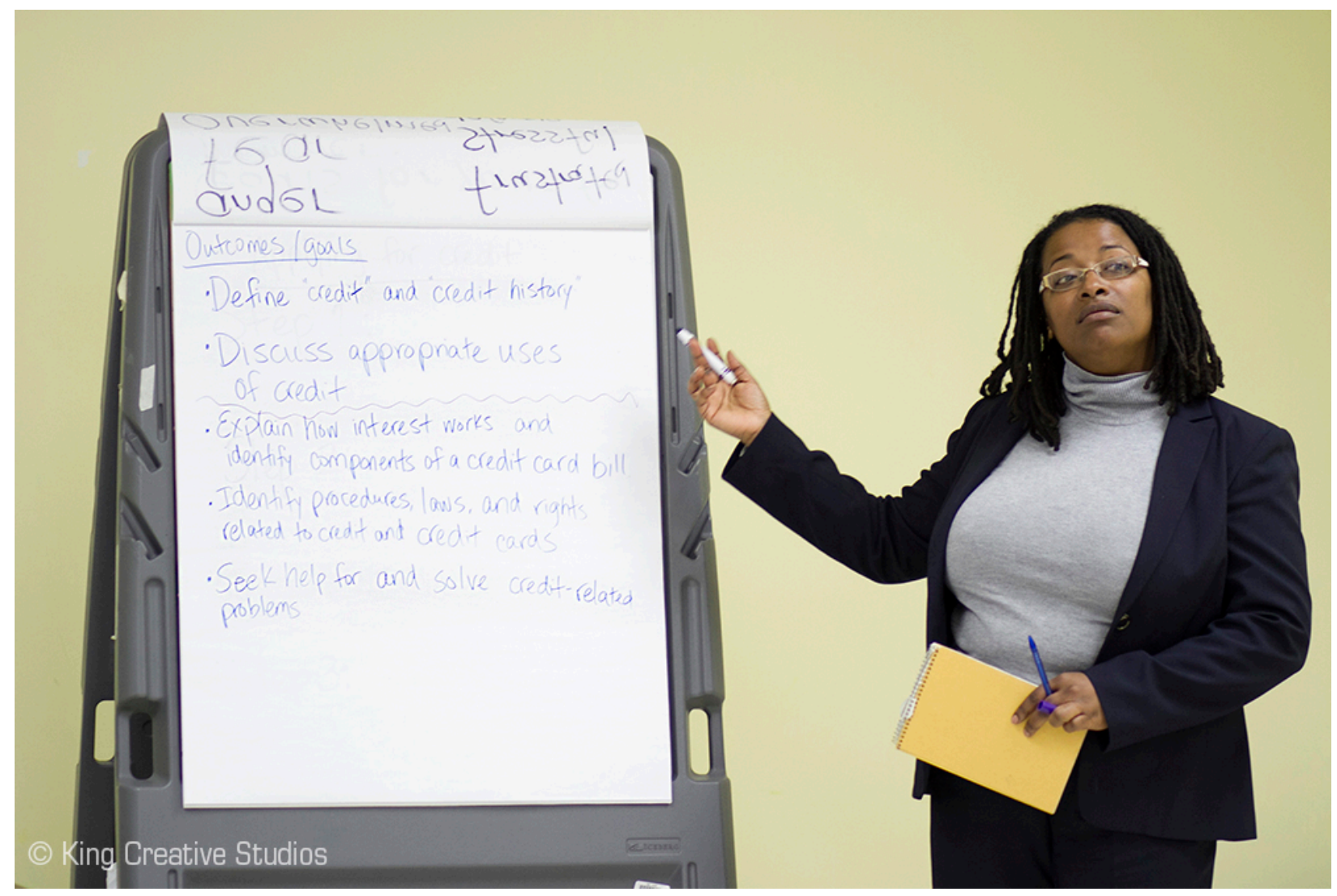

By 2016, more than 1,400 lawyers from across the U.S. were volunteering an average of 10 hours per year in Street Law's Pipeline Programs. Program evaluations have shown that participating students learn civil law and increase their interest in a legal career as a result of participation.

\section{International Street Law Programs in the 2000s}

The U.S. Department of Education recognized the value of Street Law-style programming in international education settings when it funded the Democracy Education Exchange Program and Deliberating in a Democracy-two partnership programs among Street Law, Constitutional Rights Foundation, and Constitutional Rights Foundation Chicago.

The programs promoted civic education and democratic institutions in Eastern and 
Central Europe and Latin America. Groups of teachers and program staff traveled between countries to conduct workshops and classroom visits. Students connected across borders through video conferences to deliberate practical law and democracy issues. ${ }^{26}$

In 2004, Street Law partnered with the Center for the Study of Islam and Democracy ${ }^{27}$ to create an adaptation of Democracy for All that included excerpts from the Koran to illustrate how Islam and democracy are compatible. The resulting text, Islam and Democracy: Toward Effective Citizenship, published in Arabic, has been used successfully in a number of countries including Morocco, Tunisia, Jordan, and Egypt. ${ }^{28}$

In 2008 Street Law's longtime executive director Ed O'Brien retired; he was succeeded by the organization's associate director and Street Law textbook co-author, Lee Arbetman. In the years following his retirement, $\mathrm{O}^{\prime}$ Brien was frequently honored for his visionary work in the areas of human rights education and global democracy building.

\section{Street Law's Continued Success with American Teens}

In 2004, Street Law began its Youth in Transition program, providing lessons for teens aging out of the foster care system. Several of the companies and law firms involved in the Legal Diversity Pipeline Program also provided volunteers to teach these lessons in

\footnotetext{
${ }^{26}$ Deliberating in a Democracy specifically focused on using the deliberation teaching strategy, and the project's website is a rich resource of deliberation materials in English, Spanish, and Russian: www.deliberating.org

${ }^{27}$ Center for the Study of Islam and Democracy: www.csidonline.org

${ }^{28}$ Center for the Study of Islam and Democracy and Street Law, Inc. Islam and Democracy: Toward Effective Citizenship. 2005.
} 
community settings. In 2015, Street Law brought its programs for vulnerable youthParents and the Law, Youth in Transition, and programs in the justice system-under the curricular umbrella of Legal Life Skills, and a revised set of practical, learner-centered lessons was completed.

\section{The 2010s: New Programs and Practices}

During the first half of the 2010s, Street Law continued to grow its partnership programs with corporate law departments and law firms. International work continued in Turkey, Indonesia, Haiti and Ukraine. Strategically, Street Law developed promising partnerships with larger international development organizations enabling its democracy and rule of law programming to be delivered in the context of broader civil society building efforts.

In 2013, Street Law began work with its publishing partner, McGraw-Hill Education, to co-author a new version of United States Government: Our Democracy. ${ }^{29}$ This high school textbook, published in 2016, incorporated the best in Street Law pedagogy. It is designed to help students "do" democracy, not just learn about it. Completion of a government course is a high school graduation requirement in most states in the U.S.; therefore, this

\footnotetext{
${ }^{29}$ Remy, Richard C., Donald A. Ritchie, Lee Arbetman, Megan L. Hanson, and Lena Morreale Scott. United States Government: Our Democracy. Columbus, OH: McGraw Hill Education, 2016.
} 
new publication has tremendous potential for reaching young people and advancing Street Law's mission.

In the initial issue of the new International Journal for Public Legal Education a critical, early step was taken toward addressing the need for proof of concept for Street Law programs. Dr. Sean Arthurs and a number of Street Law colleagues published "Is It Possible to Go from Zero to 60? An Evaluation of One Effort to Build Belief, Capacity and Commitment to Street Law in One Weekend." 30 This article details the power of Street Law training to prepare law students in Ireland and Scotland to deliver interactive practical law lessons to teenagers. The article also summarizes earlier proof of concept work and (hopefully) sets the stage for further research on the impact of Street Law programs.

In 2017, Street Law began an ambitious project in collaboration with PACT and a consortium of Ukrainian NGOs to develop civic education materials, teacher education, and a new required $10^{\text {th }}$ grade civics course for Ukrainian high school students.

\section{Street Law's Future}

What accounts for Street Law's staying power in the U.S. and around the world after 45 years, and why does this program continue to appeal to new audiences? The answer

\footnotetext{
30 Arthurs, Seán, Melinda Cooperman, Jessica Gallagher, Freda Grealy, John Lunney, Rob Marrs, and Richard Roe. "Is it possible to go from Zero to 60? An evaluation of one effort to build Belief, Capacity, and Community in Street Law Instructors in One Weekend.” International Journal of Public Legal Education: Vol. 1, No. 1 (2017). www.northumbriajournals.co.uk
} 
likely lies in a combination of Street Law's practical, accessible content (adjusted for each country and culture); interactive pedagogy, which helps people develop their civic voice; and deep community involvement that brings professionals from the education, law, and law enforcement fields together to deliver programs.

In 2018, Street Law, Inc. and its many partners around the world are poised for continued success. Despite some (hopefully only temporary) backsliding in terms of human rights in the U.S. and abroad, the arc of history bends toward democratic development, and Street Law programs are a critical element of establishing a just and fair world. 